\title{
Parkin regulates translesion DNA synthesis in response to UV radiation
}

\author{
Xuefei Zhu ${ }^{1, *}{ }^{,}$Xiaolu Ma ${ }^{2, *}$, Yingfeng Tu ${ }^{1, *}$, Min Huang ${ }^{2}$, Hongmei Liu ${ }^{1}$, Fengli Wang ${ }^{1}$, \\ Juanjuan Gong ${ }^{1}$, Jiuqiang Wang ${ }^{1}$, Xiaoling $\mathrm{Li}^{1}$, Qian Chen ${ }^{1}$, Hongyan Shen ${ }^{2}$, Shu \\ Zhu' ${ }^{1}$, Yun Wang ${ }^{1}$, Yang Líu' ${ }^{2}$, Caixia Guo ${ }^{2}$, Tie-Shan Tang ${ }^{1}$ \\ ${ }^{1}$ State Key Laboratory of Membrane Biology, Institute of Zoology, University of Chinese Academy of Sciences, Chinese \\ Academy of Sciences, Beijing 100101, China \\ ${ }^{2}$ CAS Key Laboratory of Genomics and Precision Medicine, Beijing Institute of Genomics, University of Chinese Academy of \\ Sciences, Chinese Academy of Sciences, Beijing 100101, China \\ *These authors contributed equally to this work \\ Correspondence to: Caixia Guo, email: guocx@big.ac.cn \\ Tie-Shan Tang, email: tangtsh@ioz.ac.cn
}

Keywords: Parkin, translesion DNA synthesis, ultraviolet radiation, melanoma, Parkinson's disease

Received: January 23, 2017 Accepted: March 27, $2017 \quad$ Published: April 05, 2017

Copyright: Zhu et al. This is an open-access article distributed under the terms of the Creative Commons Attribution License (CC-BY), which permits unrestricted use, distribution, and reproduction in any medium, provided the original author and source are credited.

\section{ABSTRACT}

Deficiency of Parkin is a major cause of early-onset Parkinson's disease (PD). Notably, PD patients also exhibit a significantly higher risk in melanoma and other skin tumors, while the mechanism remains largely unknown. In this study, we show that depletion of Parkin causes compromised cell viability and genome stability after ultraviolet (UV) radiation. We demonstrate that Parkin promotes efficient Rad18dependent proliferating cell nuclear antigen (PCNA) monoubiquitination by facilitating the formation of Replication protein A (RPA)-coated SSDNA upon UV radiation. Furthermore, Parkin is found to physically interact with NBS1 (Nijmegen breakage syndrome 1), and to be required for optimal recruitment of NBS1 and DNA polymerase eta (Poln) to UV-induced damage sites. Consequently, depletion of Parkin leads to increased UV-induced mutagenesis. These findings unveil an important role of Parkin in protecting genome stability through positively regulating translesion DNA synthesis (TLS) upon UV damage, providing a novel mechanistic link between Parkin deficiency and predisposition to skin cancers in PD patients.

\section{INTRODUCTION}

PARK2 gene, which is frequently found mutated in early-onset Parkinson's disease (PD) [1, 2], encodes an evolutionarily conserved RING-between-RING E3 ubiquitin ligase Parkin [3, 4]. In addition to being associated with the progression of parkinsonism [5-7], Parkin deficiency is also frequently detected in a broad spectrum of tumors and tumor-derived cell lines, including melanoma, glioma, ovarian cancer, cervical cancer, lung cancer, hepatocellular carcinoma, colorectal cancer, and gastric cancer [8-11]. Parkin knockout mice also exhibit higher susceptibility to tumorigenesis [12,13], suggesting a role of Parkin in suppressing tumorigenesis. Several biological functions of Parkin have been implicated in tumor suppression $[9,10,13]$, such as the role as a pivotal mediator of mitophagy [14-19] and the role as a regulator of cell cycle progression [20, 21]. However, more precise mechanism for Parkin's function in preventing carcinogenesis still needs to be elucidated.

Translesion DNA synthesis (TLS) is one mode of DNA damage tolerance, which utilizes specialized TLS polymerases to sustain DNA synthesis when encountering

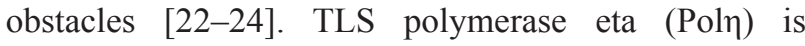
specifically required for error-free bypass of UV-induced cyclobutane pyrimidine dimers (CPDs) [25]. Inactivation of Pol $\eta$ is highly related to UV-induced mutagenesis and Pol $\eta$ deficiency lead to a variant form of the human genetic disorder xeroderma pigmentosum (XPV) [26], a disease characterized by an early predisposition to skin cancer. TLS pathway is known to be efficiently triggered by replication stress, such as UV, which leads to uncoupling of replicative polymerase and helicase activities [27], and thereby stretches of single-stranded DNA (ssDNA). SsDNA could be rapidly bound by Replication protein A (RPA), which recruits an E3 ligase 
Rad18 to stalled replication forks to catalyze PCNA monoubiquitination [28]. Emerging evidences show that the monoubiquitinated PCNA (PCNA-mUb) has a higher affinity with TLS polymerases [29-33]. Therefore, PCNA$\mathrm{mUb}$ is believed to play a key role in orchestrating TLS, which is closely related to genome mutagenesis and genome integrity. The monoubiquitination of PCNA is known to be mediated by Rad1 8 together with E2 enzyme Rad6 after exposure to replication stress [34, 35], or mediated by CRL4 ${ }^{\mathrm{Cd} t 2}$ complex in unperturbed state [36]. Recently, several factors, such as BRCA1 (breast cancer type 1 susceptibility protein) [37], NBS1 (Nijmegen breakage syndrome 1) [38], Chk1(checkpoint kinase 1) [39], SIVA1 [40], Spartan [41], ZBTB1 [42], MSH2 [43], Poln [44], REV1 [45], and MAGE-A4 (melanoma Antigen A4) [46], have been identified to regulate TLS in different ways, indicating that TLS is intricately regulated at multiple steps.

In this study, we discovered that Parkin is required for efficient ssDNA generation after UV radiation. Depletion of Parkin impairs UV-induced RPA foci formation. Parkin physically interacts with NBS1 and promotes NBS1 foci formation after exposure to UV radiation. In line with those, UV-induced PCNA-mUb and Pol $\eta$ recruitment are seriously compromised in Parkin-null cells. These results therefore unravel a novel function of Parkin in positive regulation of TLS, providing a new vision for the connection between Parkin deficiency and human malignancy.

\section{RESULTS}

\section{Parkin-null cells are hypersensitive to UV radiation}

PD patients are known to be more susceptible to melanoma [47-49]. Given that the frequency of Parkin mutations or deletions is relatively high in melanoma samples, and Parkin expression usually fails to be detected in melanoma-derived cell lines $[8,50]$, it is therefore tempting to speculate that Parkin might play an important role in cellular response to UV radiation. To test this possibility, we established wild-type (WT) and Parkin-/- (KO) MEF cell lines (Figure 1A), and tested their viability after exposure to UV radiation through colony assay. Results showed that Parkin-null cells were more sensitive to UV radiation comparing with WT cells (Figure 1B), and complementation with Parkin in Parkinnull cells significantly improved cell viability after UV radiation (Figure 1B), confirming that loss of Parkin was responsible for the hypersensitivity of Parkin-null cells to UV. To further detect the genotoxic effect of UV to WT and Parkin-null cells, we performed a micronucleus test, and found that Parkin-null cells exhibited an increased micronucleus rate after exposure to UV radiation comparing with WT cells (Figure 1C-1D), suggesting that loss of Parkin leads to severe genome instability. All these results collectively indicate that Parkin-null cells are hypersensitive to UV radiation, and Parkin may be important for cellular response to UV-induced DNA damage.

\section{Parkin promotes PCNA monoubiquitination after $\mathrm{UV}$ radiation}

To understand how Parkin functions in cellular response to UV radiation, we performed a tandem affinity purification to identify Parkin-associated proteins. Mass spectrum analysis identified many Parkin associated proteins including PCNA (Figure 2A). To confirm the association between Parkin and PCNA, we performed endogenous immunoprecipitation with an anti-Parkin antibody in HEK293T cells and found that these two proteins interact with each other (Figure 2B), which is in line with a previous report [51]. Meanwhile, we also confirmed the interaction in Parkin-null MEF cells stably expressing Flag-Parkin through immunoprecipitation with an anti-PCNA antibody (Figure 2C). Albeit both Parkin and PCNA could bind to DNA $[52,53]$, we found that their association was not mediated by DNA (Figure 2D). It is known that PCNA can be monoubiquitinated at K164 after UV radiation [34]. We wondered whether this modification affects the interaction between PCNA and Parkin. We performed half-endogenous immunoprecipitation with an anti-Parkin antibody in HEK293T cells ectopically expressing Flag-PCNA or Flag-PCNA ${ }^{\mathrm{K} 164 \mathrm{R}}$, and found that the association between Parkin and PCNA was not affected in the presence of K164R mutation (Supplementary Figure 1). Given that PCNA monoubiquitination is a pivotal step mediating the lesion bypass upon UV radiation and Parkin-null cells exhibit hypersensitivity to UV, we further examined whether Parkin could regulate UVinduced PCNA monoubiquitination. WT and Parkin-null cells were exposed to UV radiation. Interestingly, Parkinnull cells exhibited notably compromised PCNA-mUb in response to UV radiation (Figure $2 \mathrm{E}$ ). To confirm that Parkin deficiency accounted for the defect, we performed a rescue experiment, and found that complementation with Parkin in Parkin-null cells effectively enhanced PCNA$\mathrm{mUb}$ upon UV radiation (Figure $2 \mathrm{~F}$ ), supporting a role of Parkin in promoting PCNA-mUb in response to UV radiation.

\section{Parkin promotes Rad18-dependent PCNA monoubiquitination}

As Parkin is required for efficient PCNA monoubiquitination, and it is well established that Rad18 mediates the monoubiquitination of PCNA after exposure to UV radiation [35], we wondered whether Parkin regulates this process. U2OS cells ectopically expressing Myc-Rad18, Parkin or Myc-Rad18 and Parkin were 
collected to examine PCNA-mUb after exposure to UV radiation. Our data showed that overexpression of either Rad18 or Parkin could enhance PCNA monoubiquitination. In addition, ectopic co-expression of Rad18 and Parkin promoted PCNA-mUb to a higher extent comparing with overexpression of Rad18 alone (Figure 3A). Considering the E3 ligase activity of Parkin, it is plausible that Parkin may mediate PCNA-mUb in a Rad18-independent manner. To test this possibility, WT and Rad18-null U2OS cells were transfected with Parkin expression vector and exposed to UV radiation. We found that overexpression of Parkin in WT but not Rad18-null U2OS cells could increase PCNA-mUb level after UV radiation (Figure 3B), indicating that Parkin promotes PCNA-mUb after UV radiation in a Rad18-dependent manner. In line with it, ectopic expression of Parkin enhanced Rad18 recruitment to UV-induced damage sites (Figure 3C-3D).

\section{Parkin facilitates ssDNA generation and efficient RPA recruitment in response to $\mathrm{UV}$ radiation}

Given that Parkin promoted Rad18-mediated PCNA-mUb and Rad18 recruitment after UV radiation, it is likely that Parkin might function at the upstream of $\operatorname{Rad} 18$. RPA is a protein reported to facilitate $\operatorname{Rad} 18$ recuitment [28]. Here we found that Parkin had a strong association with RPA (Supplementary Figure 2A), and their interaction was dramatically compromised in the presence of EB (Supplementary Figure 2B), indicating that the interaction was largely mediated through DNA. It is known that RPA-ssDNA can serve as a platform for the recruitment of $\operatorname{Rad} 18$ to initiate TLS. We further tested whether Parkin was involved in the modulation of RPA recruitment upon UV radiation. WT and Parkin-null cells were exposed to UV radiation, and the percentage of RPA32-foci-positive cells at $2 \mathrm{~h}$ post-UV was quantified. Comparing with WT cells, Parkin-null cells exhibited a significant reduction in UV-induced RPA foci formation (Figure 4A-4B). We also compared the chromatin loading of RPA in WT and Parkin-null cells upon UV radiation, and found that the amount of chromatinassociated RPA was remarkably decreased in Parkin-null cells after recovering from UV radiation for $2 \mathrm{~h}$ (Figure 4C). To further verify the indispensability of Parkin in optimal UV-induced RPA recruitment, we performed a rescue experiment in Parkin-null cells. We found
A

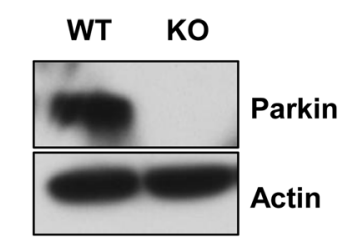

C
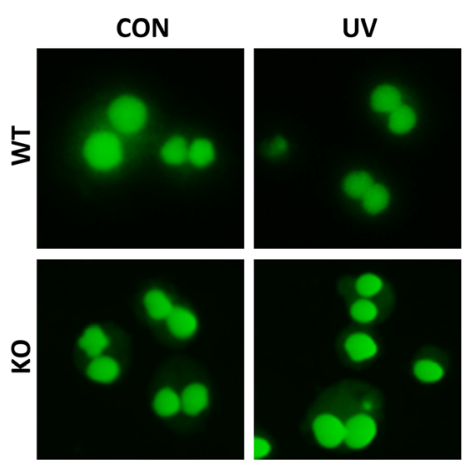

B

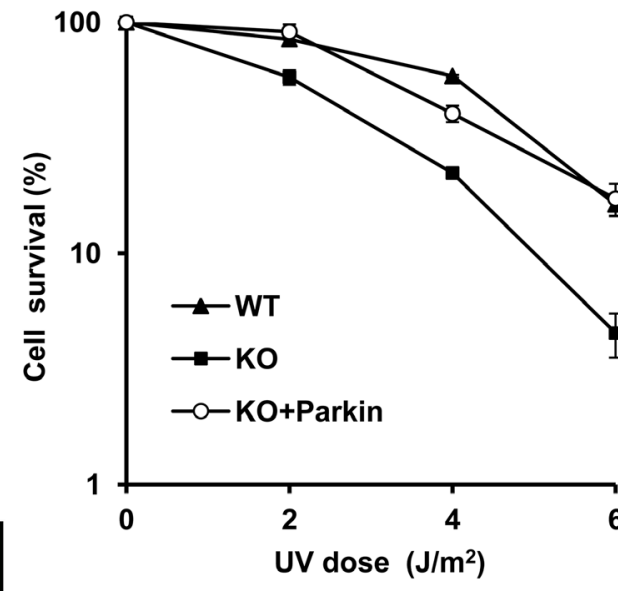

D

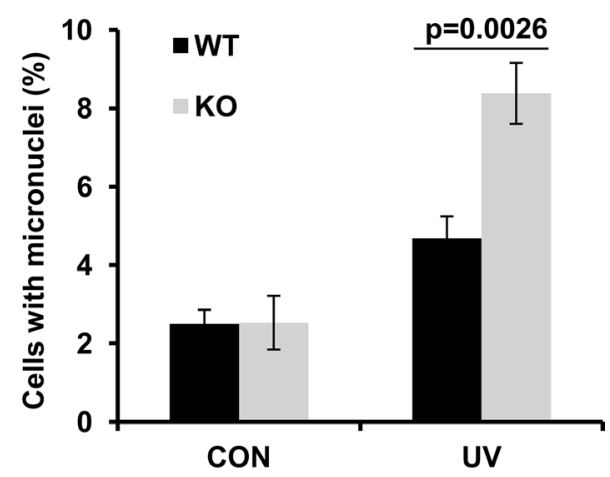

Figure 1: Parkin-null cells are hypersensitive to UV radiation. (A) Expression of Parkin in WT and Parkin-/- cells were examined by western-blot with an anti-Parkin antibody. $\beta$-actin: loading control. (B) Viability of cells after exposure to UV radiation. WT, Parkin-/-, and Parkin-/- cells complemented with Parkin were irradiated with the indicated doses of UV, and further incubated in complete medium for 10 days, then cell colonies were determined. Cell viability was expressed as a percentage of mock-treated cells. Error bars represent SD, $t$-test, $n=3$. (C-D) WT and Parkin-/- cells were irradiated with $2 \mathrm{~J} / \mathrm{m}^{2} \mathrm{UV}$, and further incubated in complete medium containing $6 \mu \mathrm{g} / \mathrm{ml} \mathrm{CB}$ for $48 \mathrm{~h}$. Then percentage of cells with micronuclei was determined. (C) Representative images of control and UVirradiated WT and Parkin-/- cells in micronucleus test. (D) Quantification of the percentage of cells with micronuclei. Error bars represent SD. $t$-test, $n=3$. 


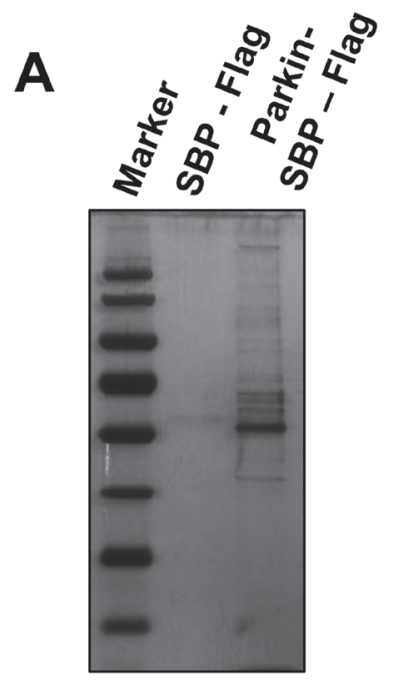

\begin{tabular}{cc} 
Protein & Peptides \\
\hline Parkin & 16 \\
PCNA & 9 \\
TDP43 & 6 \\
CHIP & 3
\end{tabular}

$\mathbf{E}$

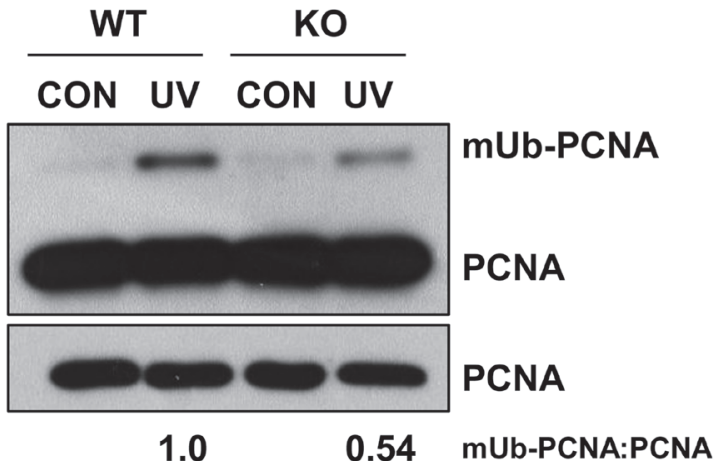

B

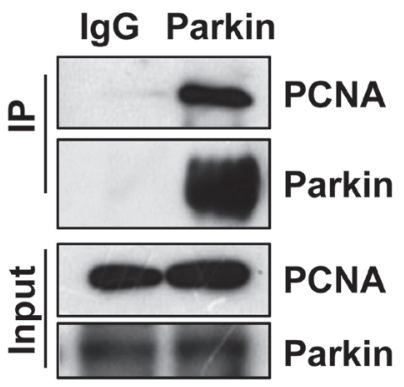

293T
C

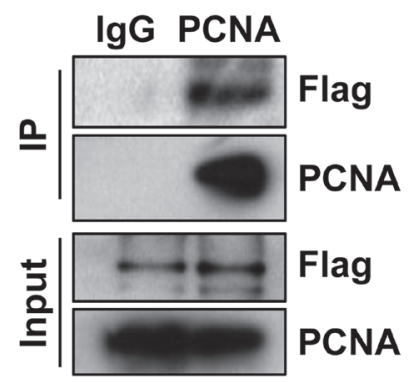

KO+Flag-Parkin
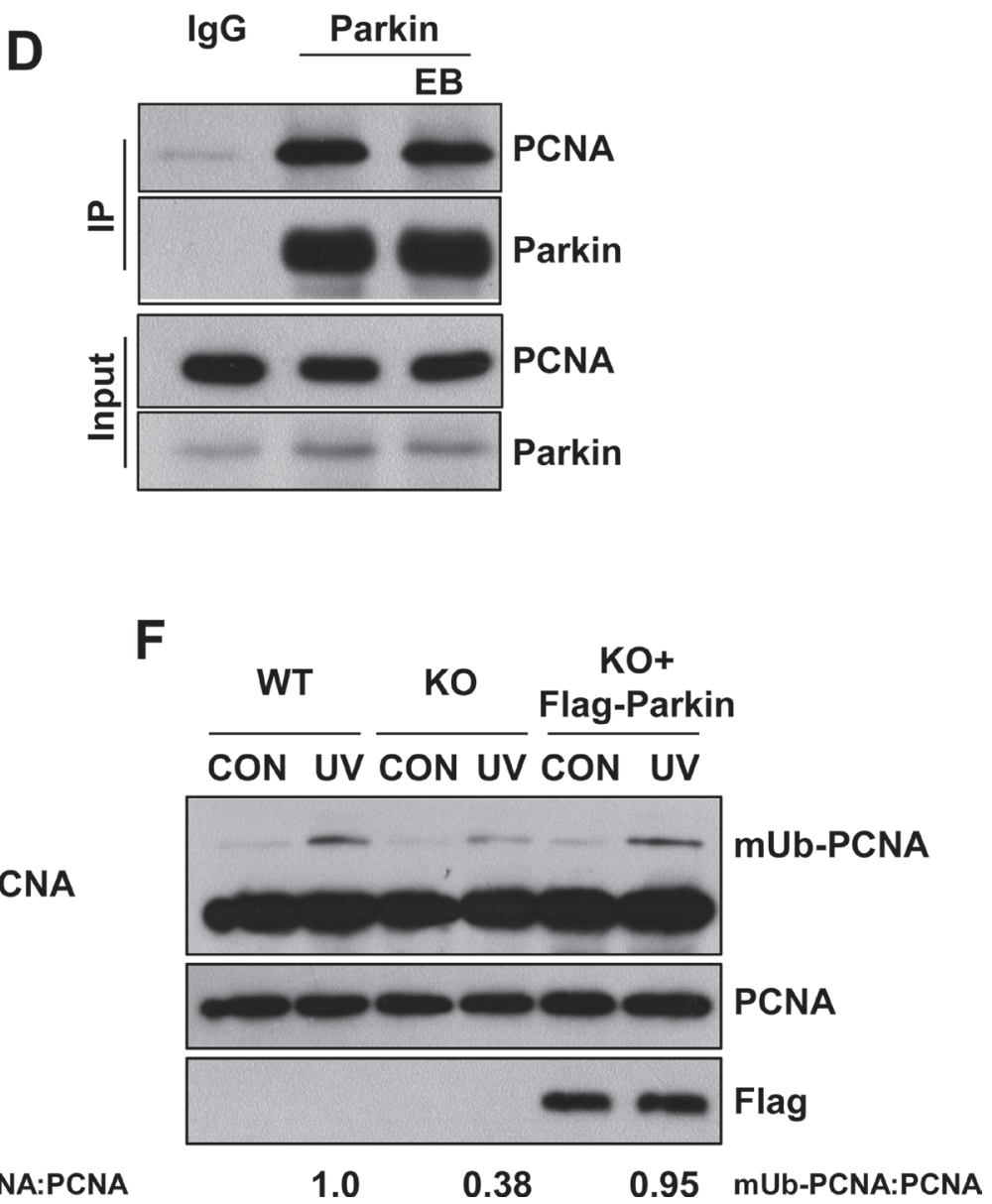

Figure 2: Parkin promotes PCNA monoubiquitination after exposure to UV radiation. (A) HEK293T cells ectopically expressing empty vector or Parkin-SBP-Flag were used for tandem affinity purification as described in "Materials and Methods". The final eluates were resolved by SDS-PAGE and revealed by silver staining. Representative proteins identified by mass spectrum were shown below. (B) HEK293T cells were lysed and incubated with protein A/G agarose conjugated with normal rabbit IgG or anti-Parkin antibody, the immunoprecipitates were then examined via western blot with antibodies against PCNA and Parkin. (C) Parkin-/- cells stably expressing Flag-Parkin were lysed and incubated with protein $\mathrm{A} / \mathrm{G}$ agarose conjugated with normal mouse IgG or anti-PCNA antibody, the immunoprecipitates were then examined via western blot with antibodies against PCNA and Flag. (D) HEK293T cells were lysed and incubated with protein $\mathrm{A} / \mathrm{G}$ agarose conjugated with normal rabbit IgG or anti-Parkin antibody for immunoprecipitation in the presence of EB or not, followed by blotting with the indicated antibodies. (E) WT and Parkin-/- cells were irradiated with $15 \mathrm{~J} / \mathrm{m}^{2} \mathrm{UV}$ and collected $3 \mathrm{~h}$ later. The levels of mUb-PCNA were examined by western blot with an anti-PCNA antibody. (F) WT, Parkin-/-, and Parkin-/- cells complemented with Flag-Parkin were treated and examined as in (E). 
that complementation with Parkin in Parkin-null cells remarkably enhanced RPA loading after UV radiation (Figure 4D), indicating that Parkin deficiency accounted for the compromised RPA recruitment upon UV radiation.

RPA is known to be recruited to stalled replication forks through its avid affinity with ssDNA. We then determined whether Parkin is required for ssDNA generation upon UV radiation. WT and Parkin-null cells were incubated with $10 \mu \mathrm{M}$ BrdU for $48 \mathrm{~h}$ to label genomic DNA before being irradiated with UV, followed by immunofluorescence with an anti-BrdU antibody without denaturation of DNA. Intriguingly, at $2 \mathrm{~h}$ postUV, Parkin-null cells exhibited considerable decrease in the percentage of BrdU-positive cells comparing with WT

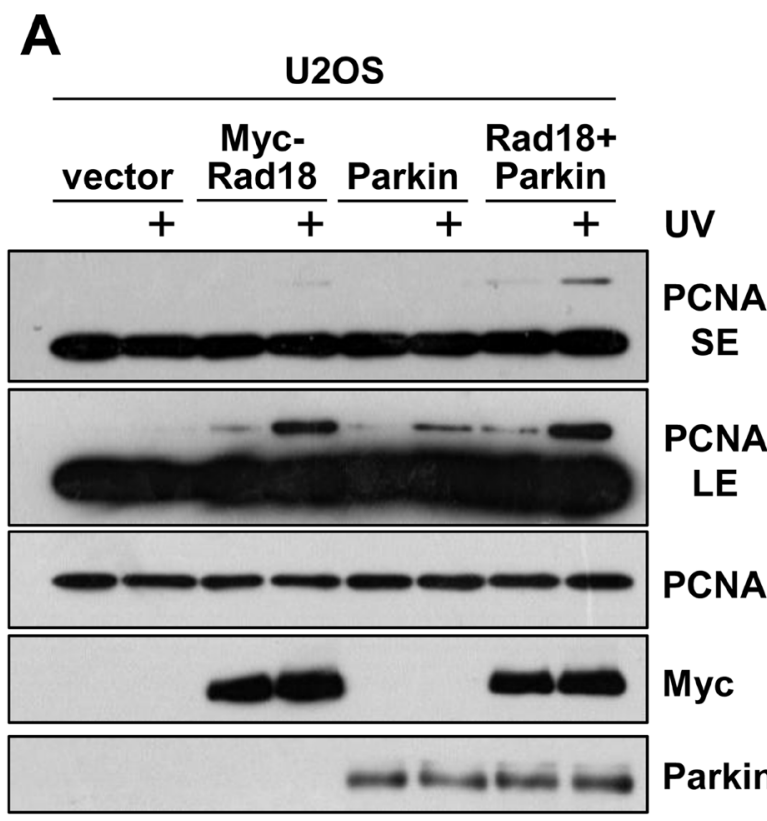

B

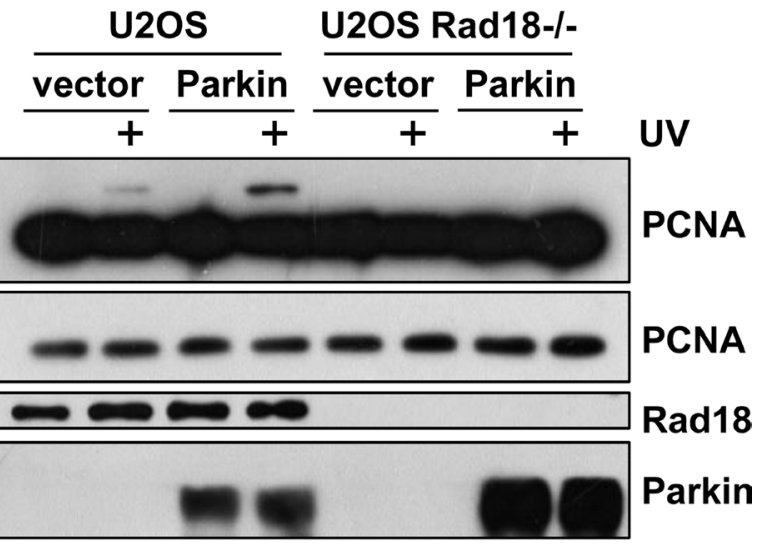

C
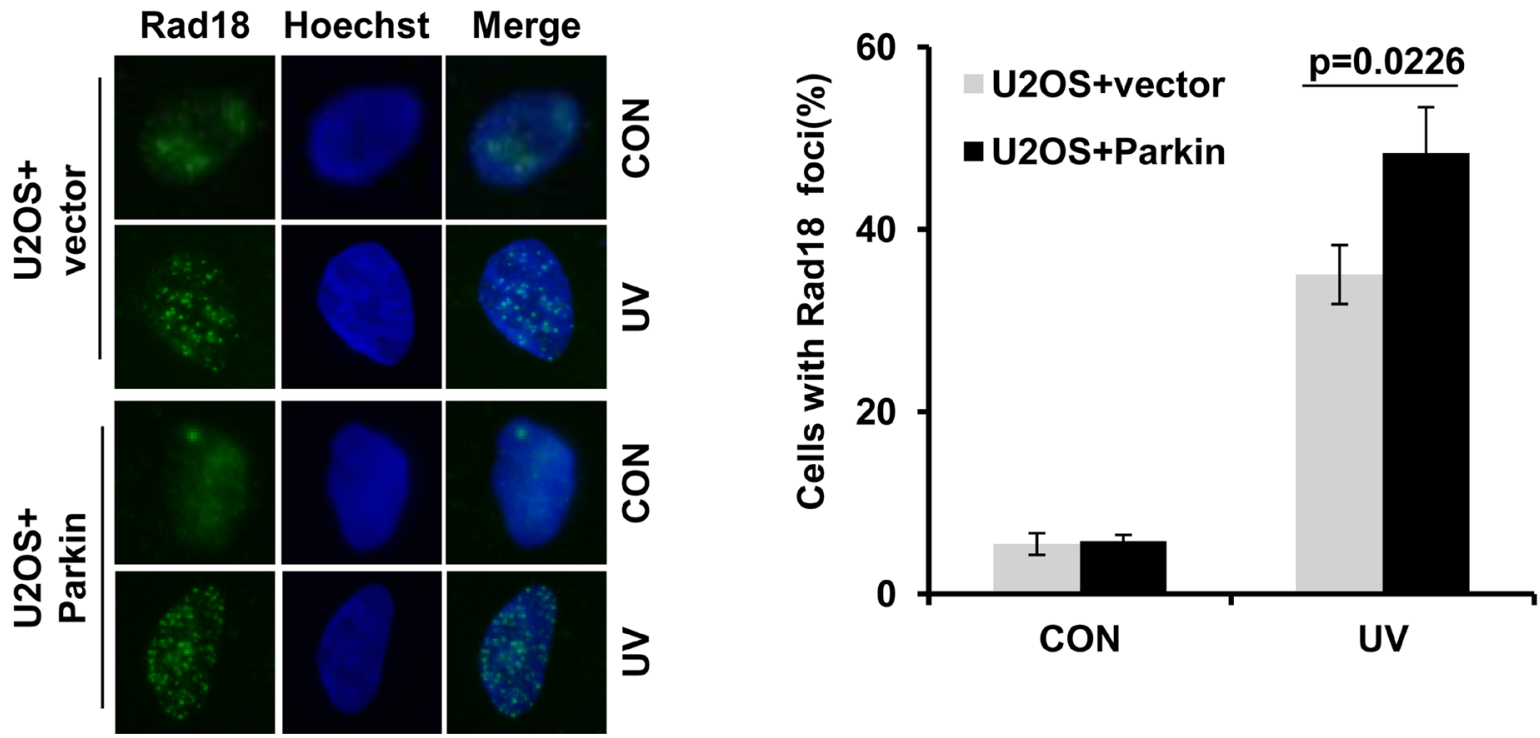

Figure 3: Parkin promotes Rad18 dependent PCNA monoubiquitination. (A) U2OS cells ectopically expressing Myc-Rad18, Parkin or Myc-Rad18 and Parkin were irradiated with $15 \mathrm{~J} / \mathrm{m}^{2} \mathrm{UV}$ and collected $3 \mathrm{~h}$ later. The levels of mUb-PCNA were examined by western blot with an anti-PCNA antibody. SE, short exposure; LE, long exposure. (B) WT and Rad18-/- U2OS cells transfected with empty vector or Parkin were treated and examined as in (A). (C-D) U2OS cells transfected with empty vector or Parkin were irradiated with $15 \mathrm{~J} / \mathrm{m}^{2} \mathrm{UV}$ and recovered for $3 \mathrm{~h}$. Cells were pre-extracted with $0.5 \%$ Triton for $10 \mathrm{~min}$ and then fixed, immunostained with anti-Rad 18 antibody and Hoechst-stained. (C) Representative images of cells stained with Hoechst or antibody against Rad18 after UV radiation. (D) Quantification of the percentage of cells with more than 20 Rad18 foci. Error bars represent SD. $t$-test, $n=3$. 
A

RPA32 Hoechst Merge

5
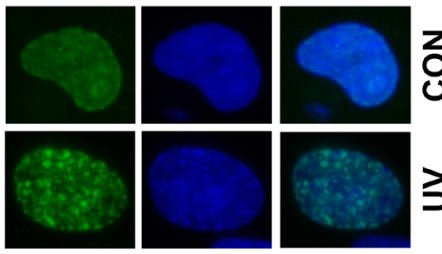

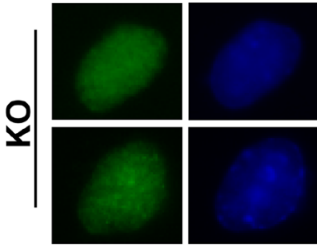

C
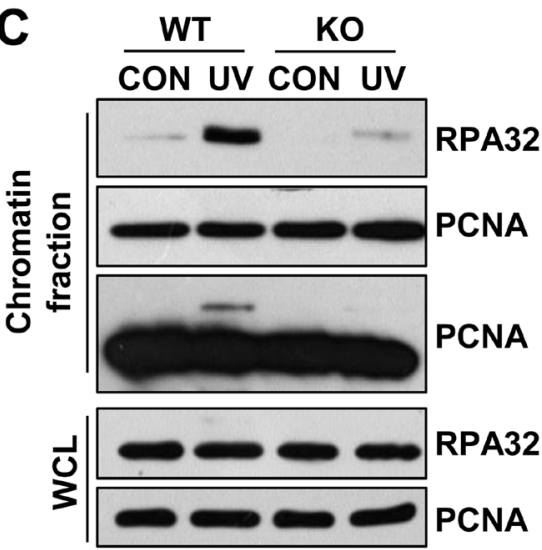

E
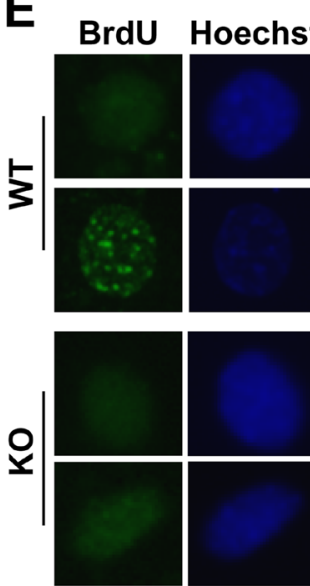
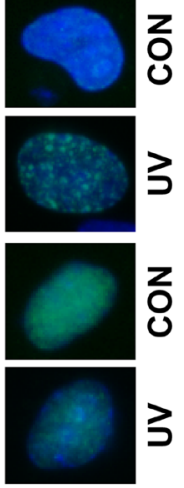

PA32

CNA

CNA

PA32

CNA

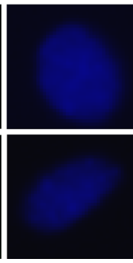

B

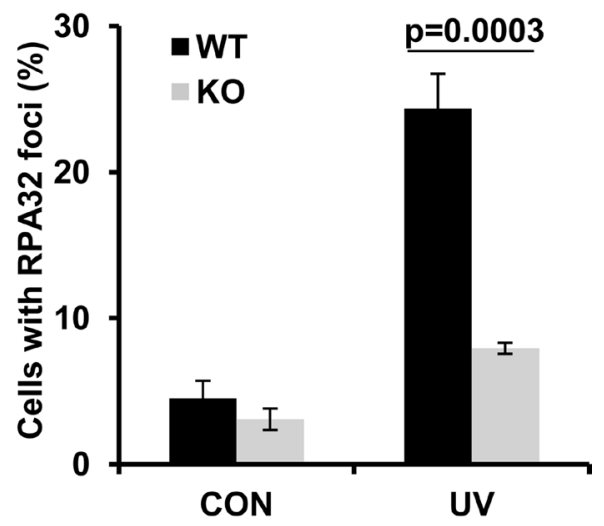

D

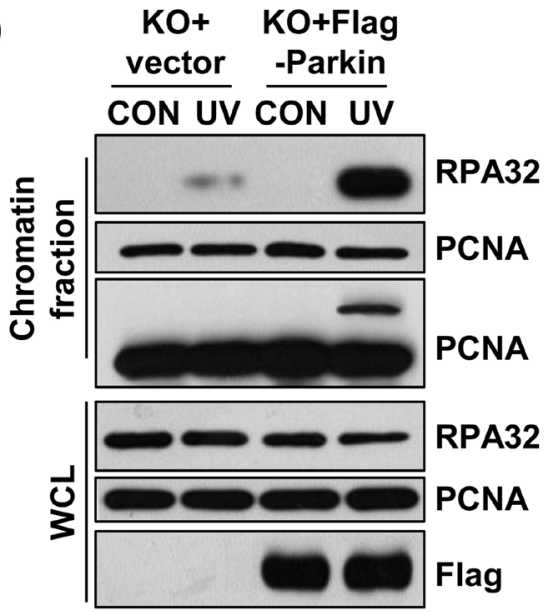

F

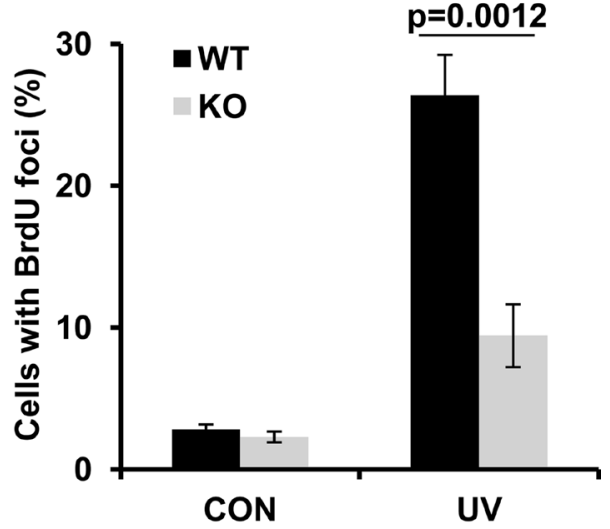

Figure 4: Parkin facilitates ssDNA generation and efficient RPA recruitment in response to UV radiation. (A-B) WT and Parkin- $/-$ cells were irradiated with $15 \mathrm{~J} / \mathrm{m}^{2} \mathrm{UV}$ and further incubated for $2 \mathrm{~h}$. Cells were pre-extracted with $0.5 \%$ Triton for 10 min and then fixed, immunostained with anti-RPA32 antibody and Hoechst-stained. (A) Representative images of cells stained with Hoechst or antibody against RPA32 after UV radiation. (B) Quantification of the percentage of cells with more than 20 RPA32 foci. Error bars represent SD. $t$-test, $n=3$. (C) WT and Parkin-l- cells were irradiated with $15 \mathrm{~J} / \mathrm{m}^{2} \mathrm{UV}$ and further incubated for $2 \mathrm{~h}$. The chromatin fraction were harvested and separated by SDS-PAGE. The levels of RPA32 were detected by western blot with an anti-RPA32 antibody. The levels of RPA32 and PCNA in whole-cell lysates (WCL) were also detected. (D) Parkin-/- cells complemented with Flag-Parkin or empty vector were treated and examined as in (C). (E-F) WT and Parkin-/- cells were incubated with $10 \mu \mathrm{M} \mathrm{BrdU}$ for $48 \mathrm{~h}$ before irradiated with $15 \mathrm{~J} /$ $\mathrm{m}^{2} \mathrm{UV}$, and further incubated for $2 \mathrm{~h}$. Cells were pre-extracted with $0.5 \%$ Triton and immunostained with anti-BrdU antibody and Hoechststained. (E) Representative images of cells stained with Hoechst or antibody against BrdU after UV radiation. (F) Quantification of the percentage of cells with more than $20 \mathrm{BrdU}$ foci. Error bars represent SD. $t$-test, $n=3$. 
cells (Figure 4E-4F), indicating that Parkin facilitates efficient ssDNA generation after exposure to UV.

\section{Parkin physically interacts with NBS1 and regulates its redistribution after $\mathrm{UV}$ radiation}

In addition to facilitate RPA recruitment, we wondered whether Parkin also regulates UV-induced Rad18 accumulation through other mode(s). Given the key role of NBS1 in RAD18 recruitment after UV radiation [38], we asked whether Parkin interacts with NBS1. Through half-endogenous and exogenous co-IP when either Parkin or NBS1 being immunoprecipated, we discovered that Parkin physically interacted with NBS1 (Figure 5A-5B), and their interaction was not mediated by DNA (Figure 5C). Given that RPA interacts with both NBS1 [54] and Parkin, we wondered whether the association between NBS1 and Parkin is mediated by RPA. We performed immunoprecipitation with an antiParkin antibody in WT and RPA32- or RPA70- depleted HEK293T cells ectopically expressing Myc-NBS1, and found that RPA deficiency didn't affect the interaction between Parkin and NBS1 (Supplementary Figure 3). Intriguingly, the Parkin/NBS1 association is under dynamic regulation after UV radiation. The interaction between Parkin and NBS1 was enhanced at $1 \mathrm{~h}$ post-UV and decreased thereafter (Figure 5D-5E).

We next examined whether Parkin regulates UV-induced NBS1 foci formation by performing immunofluorescence staining with an anti-NBS1 antibody. WT and Parkin-null cells were exposed to UV radiation, and the percentage of cells with NBS1 foci were quantified at $2 \mathrm{~h}$ post-UV. The results showed that albeit the NBS1 protein level of Parkin-null cells is comparable to that of WT cells (Supplementary Figure 4), NBS1 recruitment was significantly reduced in Parkin-null cells comparing with that in WT cells (Figure 5F-5G). We also found that complementation with Parkin in Parkin-null cells significantly enhanced NBS1 recruitment upon UV radiation (Figure 5H), indicating that Parkin promoted NBS1 recruitment to UV-induced damage sites.

We further tested whether the E3 ligase activity of Parkin is essential for its function in the regulation of TLS. We found that complementation with WT Parkin and its E3 ligase inactive mutant Parkin ${ }^{\mathrm{C} 431 \mathrm{~S}}$ [55] in Parkinnull cells enhanced the recruitment of RPA and NBS1, and PCNA-mUb to a similar extent (Supplementary Figure 5A-5B), and ectopic expression of both Parkin and Parkin ${ }^{\mathrm{C} 431 \mathrm{~B}}$ in U2OS cells increased the recruitment of Rad18 to UV-induced damage sites (Supplementary Figure 5C), indicating that the E3 ligase acivity of Parkin is dispensable in the role of Parkin in TLS regulation. In line with that, complementation with Parkin ${ }^{\mathrm{C} 431 \mathrm{~S}}$ in Parkinnull cells also improved cell viability after UV radiation (Supplementary Figure 5D-5E).

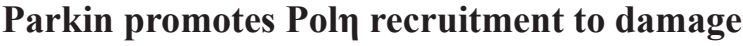 sites}

Pol $\eta$ is a TLS polymerase which is recruited to UV-induced sites of damage through its interaction with PCNA-mUb [33]. As Parkin promotes UV-induced PCNA monoubiquitination, we tested whether Parkin depletion compromised Poln recruitment after UV radiation. The percentage of GFP-Poln foci positive cells was quantified and compared in WT and Parkin-null cells irradiated with UV. Our results showed that depletion of Parkin led to dramatically reduced UV-induced Pol $\eta$ foci formation comparing to WT cells (Figure 6A-6B). Recently, Pol $\eta$ was reported to be recruited to sites of oxidative DNA damage through its interaction with PCNA-mUb after laser microirradiation [56], prompted us to ask whether Parkin also regulates this kind of Pol $\eta$ recruitment. WT and Parkin-null cells ectopically expressing GFP-Poln were then exposed to laser microirradiation, and the dynamics of GFP-Poln recruitment to damage sites were monitored. It turned out that Parkin-null cells exhibited attenuated and delayed GFP-Pol $\eta$ recruitment comparing with WT cells (Supplementary Figure 6). These results collectively indicated that Parkin was required for efficient Pol $\eta$ recruitment after DNA damage treatment.

\section{Parkin deficiency causes increased UV-induced mutagenesis}

It is reported that Pol $\eta$ deficiency leads to elevated mutation frequency after UV radiation. Based on the above results that Parkin is required for optimal Poln recruitment to UV-induced damage sites, we speculate that Parkin may also be involved in preventing UVinduced mutagenesis. The mutation frequency was then compared in WT and Parkin-deficient cells using the supF shuttle vector system $[46,57,58]$. UV-irradiated pSP189 plasmids were transfected into control and Parkindepleted HEK293T cells to replicate. Amplified pSP189 plasmids were extracted $72 \mathrm{~h}$ later for mutation frequency measurement. Our results showed that the mutation frequency of UV-damaged pSP189 plasmids in Parkindepleted cells was higher than that in control cells (Figure 6C-6D), demonstrating an important role of Parkin in preventing UV-induced mutagenesis.

\section{DISCUSSION}

During the past two decades, epidemiologic researches have presented compelling evidences that PD patients exhibit a higher incidence of melanoma [47-49, 59], while the underlying mechanism remains largely unknown. In this study, we unravel a novel function of Parkin, whose deficiency is frequently found in familial PD patients and is also found in sporadic PD patients [5, 7], in TLS regulation 

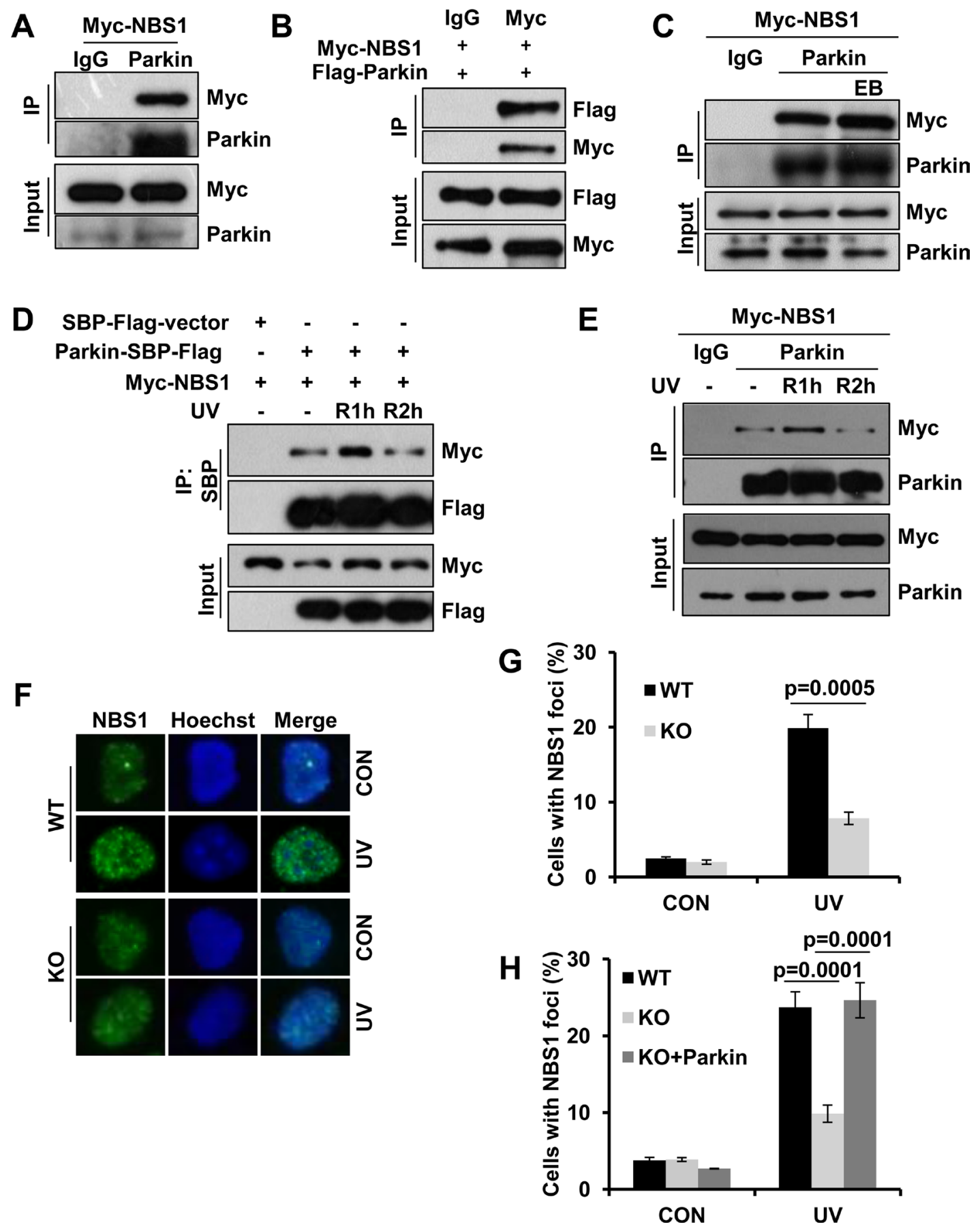

Figure 5: Parkin interacts with NBS1 and regulates its redistribution after exposure to UV radiation. (A-B) Interaction between Parkin and NBS1. HEK293T cells ectopically expressing Myc-NBS1 (A) or Myc-NBS1 and Flag-Parkin (B) were lysed and incubated with protein $\mathrm{A} / \mathrm{G}$ agarose conjugated with either anti-Parkin or anti-Myc antibody. The immunoprecipitated products were blotted with the indicated antibodies. (C) HEK293T cells ectopically expressing Myc-NBS1 were lysed and incubated with protein A/G agarose conjugated with normal rabbit IgG or anti-Parkin antibody for immunoprecipitation in the presence of EB or not, followed by blotting with the indicated antibodies. (D-E) Dynamic association between Parkin and NBS1 upon UV radiation. (D) HEK293T cells transfected with Myc-NBS1 and Parkin-SBP-Flag or empty vector were irradiated with $15 \mathrm{~J} / \mathrm{m}^{2} \mathrm{UV}$ and recovered for either $1 \mathrm{~h}$ (R1h) or $2 \mathrm{~h}$ (R2h). Cell lysates were immunoprecipitated with streptavidin-conjugated sepharose followed by blotting with the indicated antibodies. (E) HEK293T cells ectopically expressing Myc-NBS1 were treated as above. Cell lysates were immunoprecipitated with protein A/G agarose conjugated with normal rabbit IgG or anti-Parkin antibody followed by blotting with the indicated antibodies. (F-H) NBS1 foci formation after UV radiation. WT, Parkin-/- , and Parkin-/- cells complemented with Parkin were irradiated with $15 \mathrm{~J} / \mathrm{m}^{2} \mathrm{UV}$ and further incubated for $2 \mathrm{~h}$. Cells were pre-extracted with $0.5 \%$ Triton for $10 \mathrm{~min}$ and then immunostained with anti-NBS1 antibody and Hoechst-stained. (F) Representative images of cells stained with Hoechst or antibody against NBS1 after UV radiation. (G-H) Quantification of the percentage of cells with more than 20 NBS1 foci. Error bars represent SD. $t$-test, $n=3$. 
after UV radiation. We noticed that Parkin deficiency leads to reduced cell viability and chromosome stability, and increased mutagenesis upon UV radiation, indicating a protective role of Parkin in cellular response to UV radiation.

We found that, although Parkin promotes PCNA$\mathrm{mUb}$, it failed to facilitate PCNA-mUb in the absence of Rad18. Therefore, it is unlikely that Parkin could mediate PCNA-mUb directly. We also found that Parkin-null cells complemented with both WT and C431S (an E3 ligase inactive form) mutated Parkin exhibited similar levels of RPA and NBS1 recruitment, as well as comparable amounts of PCNA-mUb in response to UV radiation, hinting that the E3 ligase activity of Parkin is not essential for its function in TLS regulation. Based on our results, we propose that Parkin is likely to promote PCNA-mUb by facilitating RPA-ssDNA formation and NBS1 recruitment at UV-induced damage sites (Figure 6E).

It is known that PCNA-mUb is a key factor for optimal recruitment of Poln to stalled replication forks [33], while Poln plays an important role in protecting cells from genome instability after UV radiation $[25,60]$. Therefore, the result that Parkin promotes UVinduced Pol $\eta$ foci formation further support the protective role of Parkin in cellular response to UV exposure. Consistently, we noticed that depletion of Parkin increases the mutagenesis after UV treatment, which may explain the phenomena that Parkin deficiency leads to a higher predisposition to UV-induced skin cancer. In line with that, diminished expression of Parkin is frequently found in melanoma samples and melanoma derived cell lines [8]. Deletions and mutations of Parkin are prevalent in both familial and sporadic PD [7, 61, 62]. Some mutations of Parkin are deleterious to its E3 ligase activity, while many mutations retain the E3 ligase activity but exhibit decreased stability and increased propensity to form aggregates [63-65], leading to loss of function of Parkin. Considering the genetic relevance of Parkin with both PD and melanoma, its suppressive role in the pathogenesis of these two seemingly disparate diseases nicely interpret the higher morbidity of melanoma in PD patients.

Besides melanoma, deficiency of Parkin is also found in glioma and a wide spectrum of malignancy, where TLS process happens. Although several biological functions of Parkin [9, 10, 13], such as the role in regulating mitophagy [14-19] and cell cycle progression $[20,21]$, have been proposed to be important for its tumor suppressor function, regulation of TLS might be another considerable mechanism for Parkin to prevent tumorigenesis. It will be interesting to check whether PD patients have more genome mutation relative to the healthy controls.

There are ample evidences revealing that proper DNA damage response is important in neural development and mature nervous system, and deficiency in DNA repair could lead to a variety of neurologic disorders [66, 67]. Given the function of Parkin in positively regulating TLS, it is intriguing to further investigate whether disrupted TLS pathway due to Parkin deficiency contributes to the neurodegeneration in early-onset PD patients.

In summary, this study unravels a novel function of Parkin in regulating TLS, which explains the high incidence of melanoma and other types of skin cancer in PD patients.

\section{MATERIALS AND METHODS}

\section{Cell culture and transfection}

HEK293T and U2OS cells were obtained from the American Type Culture Collection (Rockville, MD). WT and Parkin-/- MEF cells were derived from 13.5 day-old WT and Parkin-/- [68] C57BL6/J mice embryo (The Jackson laboratory). Rad18-/- U2OS cell line was established as described previously [45]. All cells were cultured in DMEM supplemented with 10\% fetal bovine serum. Cell transfection was performed using $1 \mathrm{mg} / \mathrm{ml}$ Polyethylenimine, Linear (PEI) or Lipofectamine 2000 Transfection Reagent following the manufacturer's protocol.

\section{Plasmid constructs}

Full-length and mutant of Parkin cDNA were PCRamplified from Parkin-pIRES-GFP plasmid and subcloned into pcDNA3.1/Zeo $(+)$ or pCMV-2 $\times$ Flag-SBP (modified from $\mathrm{p} 3 \times$ Flag-CMV-14(Sigma)) vector.

Parkin-pIRES-GFP is a kind gift from Dr. Frédéric Checler. Parkin-pcDNA3.1/Zeo(+) is a kind gift from Dr. Konstanze F. Winklhofer. Myc-NBS1 is a kind gift from Dr. David J Chen.

\section{Antibodies and reagents}

Anti-Parkin polyclonal antibody was generated by immunizing rabbit with GST-Parkin (residue 258-407) fusion protein expressed and purified from E. coli. AntiPCNA (sc-56), anti-Myc (sc-40), anti-GFP (sc-8334) antibodies, and Protein A/G Plus-Agarose (sc-2003) were from Santa Cruz Biotechnology, Inc. Anti-PCNA (102052-AP) and anti-Myc (10828-1-AP) antibodies were from Proteintech Group, Inc. Anti-Parkin (CST4211) and antiRPA32 (CST2208) antibodies were from Cell Signaling Technology. Monoclonal anti-Flag M2 antibody (F1804), anti-Flag M2 affinity gel (A2220) and Cytochalasin B (857777) were from Sigma-Aldrich. Anti-Rad18 (ab57447) antibody was from Abcam. Anti-Rad18 (A301340A) was from Bethyl Laboratories, Inc. Anti-BrdU (347580) antibody was from BD Biosciences. Streptavidin Sepharose (17-5113-01) was from GE Healthcare. PEI (23966) was from Polyscienses, Inc. Lipofectamine ${ }^{\circledR}$ 2000 and Lipofectamine ${ }^{\circledR}$ RNAiMAX Transfection Reagents were from Invitrogen. 
A

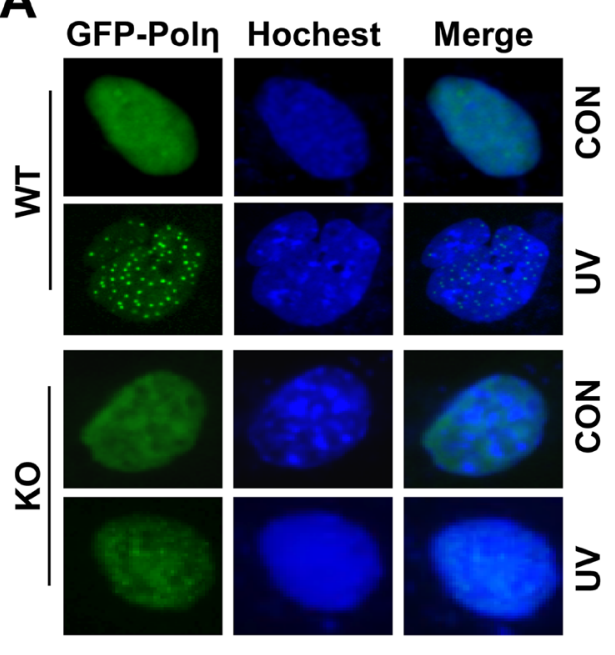

C

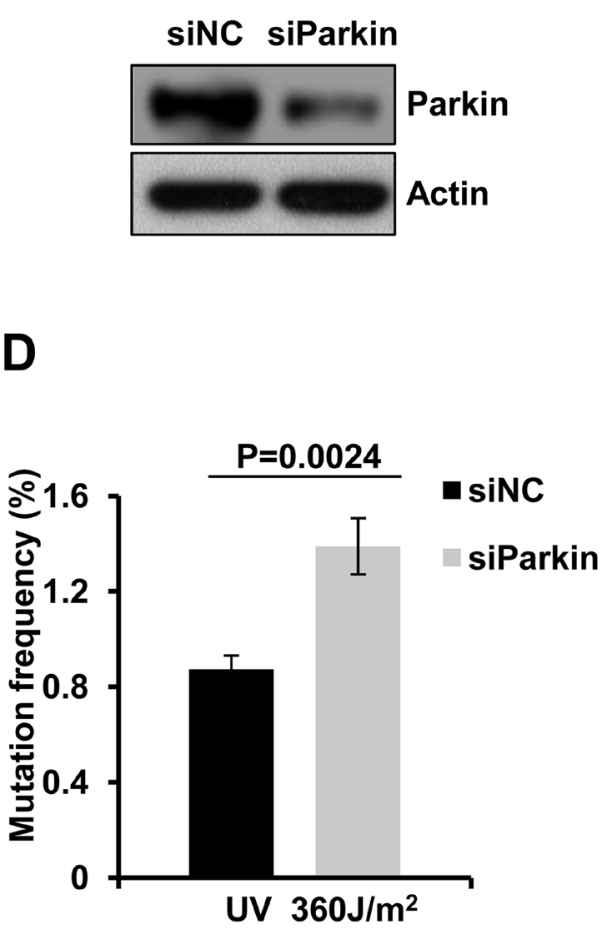

B

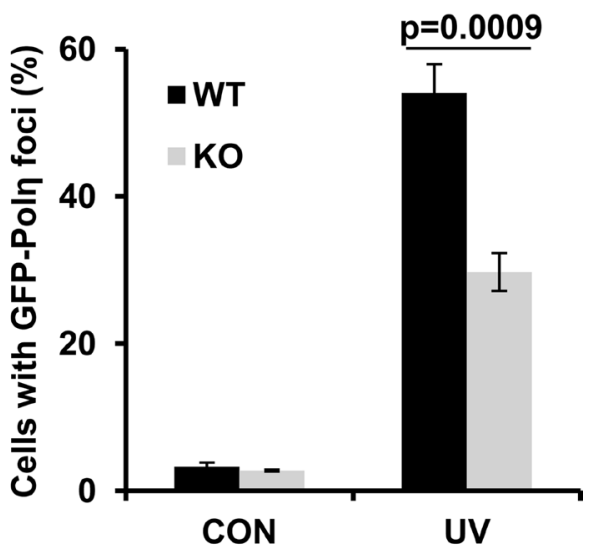

E
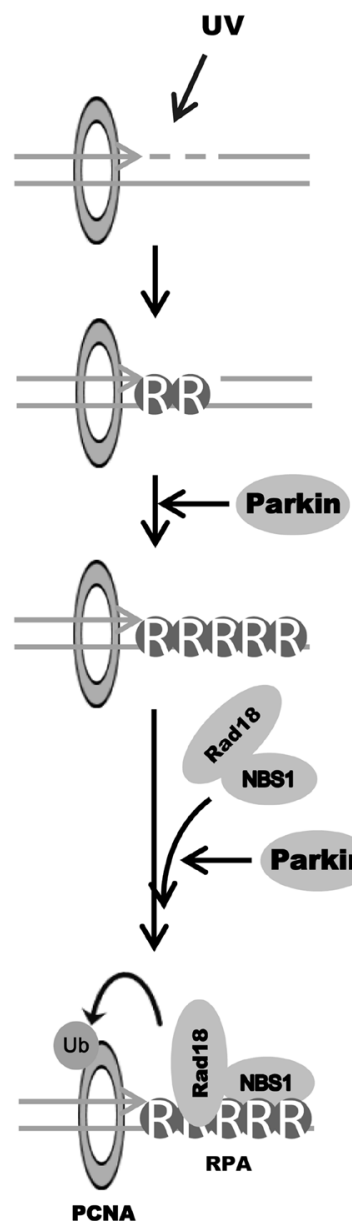

Figure 6: Parkin deficiency attenuates Pol $\eta$ recruitment to damage sites and leads to higher mutation frequency. (A-B) Parkin deficiency was detrimental for recruitment of Poln to UV-induced damage sites. WT or Parkin-/- cells transfected with GFP-Poln were irradiated with $15 \mathrm{~J} / \mathrm{m}^{2} \mathrm{UV}$ and further incubated for $8 \mathrm{~h}$. Then cells were fixed and the proportion of cells with GFP-Poln foci was determined. (A) Representative images of Poln foci formation in WT and Parkin- -- cells. (B) Quantification of the percentage of cells with more than 30 GFP-Poln foci. Error bars represent SD. $t$-test, $n=3$. (C-D) Parkin deficiency led to higher mutation frequency. (C) 293T cells were transfected with siParkin or siNC. $72 \mathrm{~h}$ later, the cells were harvested and the levels of Parkin were detected by western blot. $\beta$-actin: loading control. (D) The Parkin-depleted 293T cells were transfected with pSP189 plasmid which was pre-irradiated with $360 \mathrm{~J} /$ $\mathrm{m}^{2} \mathrm{UV}$, and replicated for $72 \mathrm{~h}$. The pSP189 plasmid was then extracted and DpnI digested followed by transformation into MBM7070 bacteria strain for mutation frequency analysis. Error bars represent SD. $t$-test, $n=3$. (E) Model for Parkin's function in regulating TLS. 


\section{Establishment of stable cell lines with lentivirus infection}

cDNAs of full length Parkin/Parkin ${ }^{\text {C431s }}$ tagged with Flag were PCR-amplified and subcloned into modified pWPXLd vector (Addgene) containing puromycin resistance. These constructs or pWPXLd empty vector were co-transfected with lentivirus package-plasmid psPAX2 and pMD2.G into HEK293T cells. Lentivirus was collected $36 \mathrm{~h}$ later, mixed with equivalent complete medium, and added to cultured Parkin-/- MEFs, incubating for $8 \mathrm{~h}$. Then cells were cultured in fresh medium for $48 \mathrm{~h}$ before screening with puromycin for individual stable cell lines.

\section{RNA interference}

The introduction of small interfering RNA (siRNA) into HEK293T cells was carried out with RNAiMAX following the manufacture's protocol. The sequences of siRNAs directed against RPA32 or RPA70 were described previously [69]. ON-TARGET plus Human PARK2 (5071) siRNA-SMART pool was from Dharmacon, Inc.

\section{Affinity purification of SBP-Flag-tagged Parkin complexes}

HEK293T cells were transiently transfected with Parkin-SBP- $2 \times$ Flag construct or the empty vector. Cells were harvested and lysed with NETN buffer [40], the supernatants were first incubated with anti-Flag M2 agarose for $2 \mathrm{~h}$. The bound proteins were eluted with $200 \mu \mathrm{g} / \mathrm{ml}$ Flag peptide in a buffer with $50 \mathrm{mM}$ Tris- $\mathrm{HCl}$ (PH7.4), $150 \mathrm{mM} \mathrm{NaCl}$. Eluted proteins were then incubated with streptavidin-conjugated sepharose for $1 \mathrm{~h}$, bound proteins were eluted with $2 \mathrm{mg} / \mathrm{ml}$ Biotin in NETN. Eluent from streptavidin-conjugated sepharose were resolved by SDSPAGE and revealed by silver staining. The excised gel bands were analyzed with mass spectrometry.

\section{Cell survival assay}

Cell survival assay following UV treatment was performed as described previously [70]. Briefly, cells were seeded into $6 \mathrm{~cm}$ dishes (about 200/dish), and incubated for $24 \mathrm{~h}$ before irradiated with indicated doses of UV. After treatment, cells were further incubated for 10 days. Then colonies were fixed and quantified. The survival of UV-exposed cells was determined by relating the cloning efficiency to that of an untreated control.

\section{Micronucleus test}

Cells were seeded into $3.5 \mathrm{~cm}$ dishes, and incubated for $24 \mathrm{~h}$. Then cells were irradiated with 0 or $2 \mathrm{~J} / \mathrm{m}^{2}$
$\mathrm{UV}$, followed by culture for $48 \mathrm{~h}$ in complete medium containing $6 \mu \mathrm{g} / \mathrm{ml}$ Cytochalasin B. Cells were then collected, rinsed in PBS, and suspended in $0.075 \mathrm{M} \mathrm{KCl}$ for $20 \mathrm{~min}$. Then cells were centrifuged at $300 \mathrm{~g}$ for $3 \mathrm{~min}$, to remove most of $\mathrm{KCl}$ hypotonic solution. Then cells were re-suspended and stained with $0.01 \%$ acridine orange. Cells with two nuclei were counted to examine micronuclei rate.

\section{Mutation frequency}

Mutation frequency was measured using the supF shuttle vector system as described previously [71]. HEK293T cells were transfected with negative control or Parkin siRNA. $48 \mathrm{~h}$ later, cells were transfected with UV-irradiated $\left(360 \mathrm{~J} / \mathrm{m}^{2}\right)$ pSP189 reporter plasmid. $72 \mathrm{~h}$ later, the pSP189 plasmids were extracted from HEK293T cells and digested with DpnI. Then pSP189 plasmids were transformed into MBM7070 bacteria strain. The transformed MBM7070 were cultured on LB plates containing X-gal, IPTG and ampicillin. The ratio of white (mutant) and blue (wild-type) colonies represent the mutation frequency in the supF coding region. The pSP189 plasmid and MBM7070 strain were gifts from Dr. M. Seidman.

\section{Preparation of chromatin fraction}

Preparation of chromatin fraction was performed as described previously [33] with some modifications. In brief, cells were rinsed with cold PBS, and incubated for 10 min on ice in CSK buffer (10 mM Pipes [pH 6.8], 100 $\mathrm{mM} \mathrm{NaCl}, 300 \mathrm{mM}$ sucrose, $3 \mathrm{mM} \mathrm{MgCl}, 1 \mathrm{mM}$ EGTA, $0.2 \%$ Triton X-100) with protease inhibitor. After rinsed with cold PBS, the cells were collected and centrifuged. The pellets were then incubated with lysis buffer (50 mM HEPES [pH 7.5], $50 \mathrm{mM} \mathrm{NaCl}, 0.05 \%$ SDS, $2 \mathrm{mM} \mathrm{MgCl}, 10 \%$ Glycerol, $0.1 \%$ Triton X-100) containing benzonase for overnight, followed by centrifuge to collect the supernatant.

\section{Immunofluorescence staining}

Cells cultured on coverslips were irradiated with $15 \mathrm{~J} / \mathrm{m}^{2} \mathrm{UV}$, and recovered for indicated time. Cells were rinsed with $\mathrm{PBS}$, and permeabilized with $0.5 \%$ Triton buffer (20 mM HEPES [pH7.4], $50 \mathrm{mM} \mathrm{NaCl}, 300 \mathrm{mM}$ sucrose, $3 \mathrm{mM} \mathrm{MgCl}$ ) for $10 \mathrm{~min}$ before fixation with $4 \%$ PFA for $20 \mathrm{~min}$ at room temperature. After blocking with 4\% BSA for $30 \mathrm{~min}$, cells were incubated with the indicated antibodies for $1 \mathrm{~h}$. After incubation with secondary Alexa Fluor 488-labeled goat-anti-rabbit or goat-anti-rat antibodies (Molecular Probes, Inc), nuclei were stained with Hoechst. Images were analyzed by fluorescent microscopy. 


\section{Immunofluorescent detection of ssDNA}

Cells were incubated with $10 \mu \mathrm{M}$ BrdU for 48 $\mathrm{h}$ prior to irradiation with $15 \mathrm{~J} / \mathrm{m}^{2} \mathrm{UV}, 2 \mathrm{~h}$ later, the cells were stained with an anti-BrdU antibody and counterstained with Hoechst as described above.

\section{ACKNOWLEDGMENTS}

We thank Dr. Huadong Pei for assistance with mass spectrum analysis. We thank Drs. Frédéric Checler, Konstanze F. Winklhofer, David J Chen, Jun Huang and Michael M. Seidman for reagents.

\section{CONFLICTS OF INTEREST}

The authors declare no conflicts of interests.

\section{FUNDING}

This study was funded by the National Natural Science Foundation of China grants 81630078, 91519324, 31570816, 81371415, 31471331, 31670822, 31470784 and 31300880, the National Basic Research Program of China (2013CB945000), the CAS Strategic Priority Research Program XDB14030300, the CAS/SAFEA International Partnership Program for Creative Research Teams (KJZD-EW-L14) and the State Key Laboratory of Membrane Biology. The funders had no role in study design, data collection and analysis, decision to publish, or preparation of the manuscript.

\section{REFERENCES}

1. Kitada T, Asakawa S, Hattori N, Matsumine $\mathrm{H}$, Yamamura Y, Minoshima S, Yokochi M, Mizuno Y, Shimizu N. Mutations in the parkin gene cause autosomal recessive juvenile parkinsonism. Nature. 1998; 392:605-8. doi: $10.1038 / 33416$.

2. Lucking CB, Durr A, Bonifati V, Vaughan J, De Michele G, Gasser T, Harhangi BS, Meco G, Denefle P, Wood NW, Agid Y, Brice A, French Parkinson's Disease Genetics Study G, et al. Association between early-onset Parkinson's disease and mutations in the parkin gene. N Engl J Med. 2000; 342:1560-7. doi: 10.1056/NEJM200005253422103.

3. Shimura H, Hattori N, Kubo S, Mizuno Y, Asakawa S, Minoshima S, Shimizu N, Iwai K, Chiba T, Tanaka K, Suzuki T. Familial Parkinson disease gene product, parkin, is a ubiquitin-protein ligase. Nat Genet. 2000; 25:302-5. doi: $10.1038 / 77060$.

4. Riley BE, Lougheed JC, Callaway K, Velasquez M, Brecht E, Nguyen L, Shaler T, Walker D, Yang Y, Regnstrom K, Diep L, Zhang Z, Chiou S, et al. Structure and function of Parkin E3 ubiquitin ligase reveals aspects of RING and HECT ligases. Nat Commun. 2013; 4:1982. doi: $10.1038 /$ ncomms2982.
5. Dawson TM, Dawson VL. The role of parkin in familial and sporadic Parkinson's disease. Mov Disord. 2010; 25:S32-9. doi: $10.1002 / \mathrm{mds} .22798$.

6. Lonskaya I, Hebron ML, Algarzae NK, Desforges N, Moussa CE. Decreased parkin solubility is associated with impairment of autophagy in the nigrostriatum of sporadic Parkinson's disease. Neuroscience. 2013; 232:90-105. doi: 10.1016/j.neuroscience.2012.12.018.

7. Morais S, Bastos-Ferreira R, Sequeiros J, Alonso I. Genomic mechanisms underlying PARK2 large deletions identified in a cohort of patients with PD. Neurol Genet. 2016; 2: e73. doi: 10.1212/NXG.0000000000000073.

8. Hu HH, Kannengiesser C, Lesage S, Andre J, Mourah S, Michel L, Descamps V, Basset-Seguin N, Bagot M, Bensussan A, Lebbe C, Deschamps L, Saiag P, et al. PARKIN Inactivation Links Parkinson's Disease to Melanoma. J Natl Cancer Inst. 2016; 108. doi: 10.1093/jnci/ djv340.

9. Lin DC, Xu L, Chen Y, Yan H, Hazawa M, Doan N, Said JW, Ding LW, Liu LZ, Yang H, Yu S, Kahn M, Yin D, et al. Genomic and Functional Analysis of the E3 Ligase PARK2 in Glioma. Cancer Res. 2015; 75:1815-27. doi: 10.1158/0008-5472.CAN-14-1433.

10. $\mathrm{Xu} \mathrm{L}$, Lin DC, Yin D, Koeffler HP. An emerging role of PARK2 in cancer. J Mol Med (Berl). 2014; 92:31-42. doi: 10.1007/s00109-013-1107-0.

11. Veeriah S, Taylor BS, Meng S, Fang F, Yilmaz E, Vivanco I, Janakiraman M, Schultz N, Hanrahan AJ, Pao W, Ladanyi M, Sander C, Heguy A, et al. Somatic mutations of the Parkinson's disease-associated gene PARK2 in glioblastoma and other human malignancies. Nat Genet. 2010; 42:77-82. doi: 10.1038/ng.491.

12. Fujiwara M, Marusawa H, Wang HQ, Iwai A, Ikeuchi K, Imai Y, Kataoka A, Nukina N, Takahashi R, Chiba T. Parkin as a tumor suppressor gene for hepatocellular carcinoma. Oncogene. 2008; 27:6002-11. doi: 10.1038/onc.2008.199.

13. Zhang $\mathrm{C}$, Lin $\mathrm{M}, \mathrm{Wu} \mathrm{R}$, Wang $\mathrm{X}$, Yang B, Levine AJ, $\mathrm{Hu} \mathrm{W}$, Feng Z. Parkin, a p53 target gene, mediates the role of p53 in glucose metabolism and the Warburg effect. Proc Natl Acad Sci USA. 2011; 108:16259-64. doi: 10.1073/ pnas. 1113884108 .

14. Palacino JJ, Sagi D, Goldberg MS, Krauss S, Motz C, Wacker M, Klose J, Shen J. Mitochondrial dysfunction and oxidative damage in parkin-deficient mice. J Biol Chem. 2004; 279:18614-22. doi: 10.1074/jbc.M401135200.

15. Zanchetta LM, Garcia A, Lyng F, Walsh J, Murphy JE. Mitophagy and mitochondrial morphology in human melanoma-derived cells post exposure to simulated sunlight. Int J Radiat Biol. 2011; 87:506-17. doi: 10.3109/09553002.2011.556175.

16. Lee J, Ham S, Lee MH, Kim SJ, Park JH, Lee SE, Chang JY, Joung KH, Kim TY, Kim JM, Sul HJ, Kweon GR, Jo YS, et al. Dysregulation of Parkin-mediated mitophagy in thyroid Hurthle cell tumors. Carcinogenesis. 2015; 36:1407-18. doi: 10.1093/carcin/bgv122. 
17. Narendra DP, Jin SM, Tanaka A, Suen DF, Gautier CA, Shen J, Cookson MR, Youle RJ. PINK1 is selectively stabilized on impaired mitochondria to activate Parkin. PLoS Biol. 2010; 8: e1000298. doi: 10.1371/journal. pbio. 1000298 .

18. Matsuda N, Sato S, Shiba K, Okatsu K, Saisho K, Gautier CA, Sou YS, Saiki S, Kawajiri S, Sato F, Kimura M, Komatsu M, Hattori N, et al. PINK1 stabilized by mitochondrial depolarization recruits Parkin to damaged mitochondria and activates latent Parkin for mitophagy. J Cell Biol. 2010; 189:211-21. doi: 10.1083/jcb.200910140.

19. Bernardini JP, Lazarou M, Dewson G. Parkin and mitophagy in cancer. Oncogene. 2016; 36:1315-1327. doi: 10.1038/onc.2016.302.

20. Gong Y, Zack TI, Morris LG, Lin K, Hukkelhoven E, Raheja R, Tan IL, Turcan S, Veeriah S, Meng S, Viale A, Schumacher SE, Palmedo P, et al. Pan-cancer genetic analysis identifies PARK2 as a master regulator of G1/S cyclins. Nat Genet. 2014; 46:588-94. doi: 10.1038/ng.2981.

21. Lee SB, Kim JJ, Nam HJ, Gao B, Yin P, Qin B, Yi SY, Ham H, Evans D, Kim SH, Zhang J, Deng M, Liu T, et al. Parkin Regulates Mitosis and Genomic Stability through Cdc20/Cdh1. Mol Cell. 2015; 60:21-34. doi: 10.1016/j. molcel.2015.08.011.

22. Chang DJ, Cimprich KA. DNA damage tolerance: when it's OK to make mistakes. Nat Chem Biol. 2009; 5:82-90. doi: 10.1038/nchembio.139.

23. Ghosal G, Chen J. DNA damage tolerance: a double-edged sword guarding the genome. Transl Cancer Res. 2013; 2:107-29. doi: 10.3978/j.issn.2218-676X.2013.04.01.

24. Guo C, Kosarek-Stancel JN, Tang TS, Friedberg EC. Y-family DNA polymerases in mammalian cells. Cell Mol Life Sci. 2009; 66:2363-81. doi: 10.1007/s00018-0090024-4.

25. Biertumpfel C, Zhao Y, Kondo Y, Ramon-Maiques S, Gregory M, Lee JY, Masutani C, Lehmann AR, Hanaoka F, Yang W. Structure and mechanism of human DNA polymerase eta. Nature. 2010; 465:1044-8. doi: 10.1038/ nature09196.

26. Masutani C, Kusumoto R, Yamada A, Dohmae N, Yokoi M, Yuasa M, Araki M, Iwai S, Takio K, Hanaoka F. The XPV (xeroderma pigmentosum variant) gene encodes human DNA polymerase eta. Nature. 1999; 399:700-4. doi: $10.1038 / 21447$.

27. Byun TS, Pacek M, Yee MC, Walter JC, Cimprich KA. Functional uncoupling of MCM helicase and DNA polymerase activities activates the ATR-dependent checkpoint. Genes Dev. 2005; 19:1040-52. doi: 10.1101/ gad.1301205.

28. Davies AA, Huttner D, Daigaku Y, Chen S, Ulrich HD. Activation of ubiquitin-dependent DNA damage bypass is mediated by replication protein a. Mol Cell. 2008; 29:62536. doi: 10.1016/j.molcel.2007.12.016.
29. Bienko M, Green CM, Crosetto N, Rudolf F, Zapart G, Coull B, Kannouche P, Wider G, Peter M, Lehmann AR, Hofmann K, Dikic I. Ubiquitin-binding domains in Y-family polymerases regulate translesion synthesis. Science. 2005; 310:1821-4. doi: 10.1126/science.1120615.

30. Guo C, Sonoda E, Tang TS, Parker JL, Bielen AB, Takeda S, Ulrich HD, Friedberg EC. REV1 protein interacts with PCNA: significance of the REV1 BRCT domain in vitro and in vivo. Mol Cell. 2006; 23:265-71. doi: 10.1016/j.molcel.2006.05.038.

31. Guo C, Tang TS, Bienko M, Dikic I, Friedberg EC. Requirements for the interaction of mouse Polkappa with ubiquitin and its biological significance. J Biol Chem. 2008; 283:4658-64. doi: 10.1074/jbc.M709275200.

32. Guo C, Tang TS, Bienko M, Parker JL, Bielen AB, Sonoda E, Takeda S, Ulrich HD, Dikic I, Friedberg EC. Ubiquitin-binding motifs in REV1 protein are required for its role in the tolerance of DNA damage. Mol Cell Biol. 2006; 26:8892-900. doi: 10.1128/MCB.01118-06.

33. Kannouche PL, Wing J, Lehmann AR. Interaction of human DNA polymerase eta with monoubiquitinated PCNA: a possible mechanism for the polymerase switch in response to DNA damage. Mol Cell. 2004; 14:491-500.

34. Hoege C, Pfander B, Moldovan GL, Pyrowolakis G, Jentsch S. RAD6-dependent DNA repair is linked to modification of PCNA by ubiquitin and SUMO. Nature. 2002; 419:135-41. doi: 10.1038/nature00991.

35. Watanabe K, Tateishi S, Kawasuji M, Tsurimoto T, Inoue H, Yamaizumi M. Rad18 guides poleta to replication stalling sites through physical interaction and PCNA monoubiquitination. EMBO J. 2004; 23:3886-96. doi: 10.1038/sj.emboj. 7600383.

36. Terai K, Abbas T, Jazaeri AA, Dutta A. CRL4(Cdt2) E3 ubiquitin ligase monoubiquitinates PCNA to promote translesion DNA synthesis. Mol Cell. 2010; 37:143-9. doi: 10.1016/j.molcel.2009.12.018.

37. Tian F, Sharma S, Zou J, Lin SY, Wang B, Rezvani K, Wang H, Parvin JD, Ludwig T, Canman CE, Zhang D. BRCA1 promotes the ubiquitination of PCNA and recruitment of translesion polymerases in response to replication blockade. Proc Natl Acad Sci USA. 2013; 110:13558-63. doi: 10.1073/pnas.1306534110.

38. Yanagihara H, Kobayashi J, Tateishi S, Kato A, Matsuura S, Tauchi H, Yamada K, Takezawa J, Sugasawa K, Masutani C, Hanaoka F, Weemaes CM, Mori T, et al. NBS1 recruits RAD18 via a RAD6-like domain and regulates Pol eta-dependent translesion DNA synthesis. Mol Cell. 2011; 43:788-97. doi: 10.1016/j.molcel.2011.07.026.

39. Yang XH, Shiotani B, Classon M, Zou L. Chk1 and Claspin potentiate PCNA ubiquitination. Genes Dev. 2008; 22:1147-52. doi: 10.1101/gad.1632808.

40. Han J, Liu T, Huen MS, Hu L, Chen Z, Huang J. SIVA1 directs the E3 ubiquitin ligase RAD18 for PCNA monoubiquitination. J Cell Biol. 2014; 205:811-27. doi: 10.1083/jcb.201311007. 
41. Centore RC, Yazinski SA, Tse A, Zou L. Spartan/ C1orf124, a reader of PCNA ubiquitylation and a regulator of UV-induced DNA damage response. Mol Cell. 2012; 46:625-35. doi: 10.1016/j.molcel.2012.05.020.

42. Kim H, Dejsuphong D, Adelmant G, Ceccaldi R, Yang K, Marto JA, D'Andrea AD. Transcriptional repressor ZBTB1 promotes chromatin remodeling and translesion DNA synthesis. Mol Cell. 2014; 54:107-18. doi: 10.1016/j. molcel.2014.02.017.

43. Lv L, Wang F, Ma X, Yang Y, Wang Z, Liu H, Li X, Liu Z, Zhang T, Huang M, Friedberg EC, Tang TS, Guo C. Mismatch repair protein $\mathrm{MSH} 2$ regulates translesion DNA synthesis following exposure of cells to UV radiation. Nucleic Acids Res. 2013; 41:10312-22. doi: 10.1093/nar/gkt793.

44. Durando M, Tateishi S, Vaziri C. A non-catalytic role of DNA polymerase eta in recruiting Rad18 and promoting PCNA monoubiquitination at stalled replication forks. Nucleic Acids Res. 2013; 41:3079-93. doi: 10.1093/nar/ gkt016.

45. Wang Z, Huang M, Ma X, Li H, Tang T, Guo C. REV1 promotes PCNA monoubiquitylation through interacting with ubiquitylated RAD18. J Cell Sci. 2016; 129:1223-33. doi: $10.1242 /$ jcs. 179408 .

46. Gao Y, Mutter-Rottmayer E, Greenwalt AM, Goldfarb D, Yan F, Yang Y, Martinez-Chacin RC, Pearce KH, Tateishi S, Major MB, Vaziri C. A neomorphic cancer cell-specific role of MAGE-A4 in trans-lesion synthesis. Nat Commun. 2016; 7: 12105. doi: 10.1038/ncomms 12105 .

47. Moller H, Mellemkjaer L, McLaughlin JK, Olsen JH. Occurrence of different cancers in patients with Parkinson's disease. BMJ. 1995; 310:1500-1.

48. Driver JA, Logroscino G, Buring JE, Gaziano JM, Kurth T. A prospective cohort study of cancer incidence following the diagnosis of Parkinson's disease. Cancer Epidemiol Biomarkers Prev. 2007; 16:1260-5. doi: 10.1158/10559965.EPI-07-0038.

49. Bertoni JM, Arlette JP, Fernandez HH, Fitzer-Attas C, Frei $\mathrm{K}$, Hassan $\mathrm{MN}$, Isaacson $\mathrm{SH}$, Lew MF, Molho E, Ondo WG, Phillips TJ, Singer C, Sutton JP, et al. Increased melanoma risk in Parkinson disease: a prospective clinicopathological study. Arch Neurol. 2010; 67:347-52. doi: 10.1001/archneurol.2010.1.

50. Levin L, Srour S, Gartner J, Kapitansky O, Qutob N, Dror S, Golan T, Dayan R, Brener R, Ziv T, Khaled M, SchuelerFurman O, Samuels Y, et al. Parkin Somatic Mutations Link Melanoma and Parkinson's Disease. J Genet Genomics. 2016; 43:369-79. doi: 10.1016/j.jgg.2016.05.005.

51. Kao SY. Regulation of DNA repair by parkin. Biochem Biophys Res Commun. 2009; 382:321-5. doi: 10.1016/j. bbrc.2009.03.048.

52. Morett E, Bork P. A novel transactivation domain in parkin. Trends Biochem Sci. 1999; 24:229-31.

53. da Costa CA, Sunyach C, Giaime E, West A, Corti O, Brice A, Safe S, Abou-Sleiman PM, Wood NW, Takahashi H,
Goldberg MS, Shen J, Checler F. Transcriptional repression of $\mathrm{p} 53$ by parkin and impairment by mutations associated with autosomal recessive juvenile Parkinson's disease. Nat Cell Biol. 2009; 11:1370-5. doi: 10.1038/ncb1981.

54. Oakley GG, Tillison K, Opiyo SA, Glanzer JG, Horn JM, Patrick SM. Physical interaction between replication protein A (RPA) and MRN: involvement of RPA2 phosphorylation and the N-terminus of RPA1. Biochemistry. 2009; 48:747381. doi: 10.1021/bi900694p.

55. Trempe JF, Sauve V, Grenier K, Seirafi M, Tang MY, Menade M, Al-Abdul-Wahid S, Krett J, Wong K, Kozlov G, Nagar B, Fon EA, Gehring K. Structure of parkin reveals mechanisms for ubiquitin ligase activation. Science. 2013; 340:1451-5. doi: 10.1126/science. 1237908 .

56. Zlatanou A, Despras E, Braz-Petta T, BoubakourAzzouz I, Pouvelle C, Stewart GS, Nakajima S, Yasui A, Ishchenko AA, Kannouche PL. The hMsh2-hMsh6 complex acts in concert with monoubiquitinated PCNA and Pol eta in response to oxidative DNA damage in human cells. Mol Cell. 2011; 43:649-62. doi: 10.1016/j.molcel.2011.06.023.

57. Parris CN, Seidman MM. A signature element distinguishes sibling and independent mutations in a shuttle vector plasmid. Gene. 1992; 117:1-5.

58. Lin JR, Zeman MK, Chen JY, Yee MC, Cimprich KA. SHPRH and HLTF act in a damage-specific manner to coordinate different forms of postreplication repair and prevent mutagenesis. Mol Cell. 2011; 42:237-49. doi: 10.1016/j.molcel.2011.02.026.

59. Disse M, Reich H, Lee PK, Schram SS. A Review of the Association Between Parkinson Disease and Malignant Melanoma. Dermatol Surg. 2016; 42:141-6. doi: 10.1097/ DSS.0000000000000591.

60. Yang W. Surviving the sun: repair and bypass of DNA UV lesions. Protein Sci. 2011; 20:1781-9. doi: 10.1002/pro.723.

61. West AB, Maidment NT. Genetics of parkin-linked disease. Hum Genet. 2004; 114:327-36. doi: 10.1007/s00439-0031074-6.

62. Oliveira SA, Scott WK, Martin ER, Nance MA, Watts RL, Hubble JP, Koller WC, Pahwa R, Stern MB, Hiner BC, Ondo WG, Allen FH Jr, Scott BL, et al. Parkin mutations and susceptibility alleles in late-onset Parkinson's disease. Ann Neurol. 2003; 53:624-9. doi: 10.1002/ana.10524.

63. Henn IH, Gostner JM, Lackner P, Tatzelt J, Winklhofer KF. Pathogenic mutations inactivate parkin by distinct mechanisms. J Neurochem. 2005; 92:114-22. doi: 10.1111/j.1471-4159.2004.02854.x.

64. Hampe C, Ardila-Osorio H, Fournier M, Brice A, Corti O. Biochemical analysis of Parkinson's disease-causing variants of Parkin, an E3 ubiquitin-protein ligase with monoubiquitylation capacity. Hum Mol Genet. 2006; 15:2059-75. doi: 10.1093/hmg/ddl131.

65. Wang C, Tan JM, Ho MW, Zaiden N, Wong SH, Chew CL, Eng PW, Lim TM, Dawson TM, Lim KL. Alterations in the solubility and intracellular localization of parkin by several familial Parkinson's disease-linked point mutations. 
J Neurochem. 2005; 93:422-31. doi: 10.1111/j.14714159.2005.03023.x.

66. McKinnon PJ. Maintaining genome stability in the nervous system. Nat Neurosci. 2013; 16:1523-9. doi: 10.1038/ nn.3537.

67. McKinnon PJ. DNA repair deficiency and neurological disease. Nat Rev Neurosci. 2009; 10:100-12. doi: 10.1038/ nrn2559.

68. Goldberg MS, Fleming SM, Palacino JJ, Cepeda C, Lam HA, Bhatnagar A, Meloni EG, Wu N, Ackerson LC, Klapstein GJ, Gajendiran M, Roth BL, Chesselet MF, et al. Parkin-deficient mice exhibit nigrostriatal deficits but not loss of dopaminergic neurons. J Biol Chem. 2003; 278:43628-35. doi: 10.1074/jbc.M308947200.

69. Grudic A, Jul-Larsen A, Haring SJ, Wold MS, Lonning PE, Bjerkvig R, Boe SO. Replication protein A prevents accumulation of single-stranded telomeric DNA in cells that use alternative lengthening of telomeres. Nucleic Acids Res. 2007; 35:7267-78. doi: 10.1093/nar/gkm738.

70. Zhang X, Lv L, Chen Q, Yuan F, Zhang T, Yang Y, Zhang H, Wang Y, Jia Y, Qian L, Chen B, Zhang Y, Friedberg EC, et al. Mouse DNA polymerase kappa has a functional role in the repair of DNA strand breaks. DNA Repair (Amst). 2013; 12:377-88. doi: 10.1016/j.dnarep.2013.02.008.

71. Parris CN, Levy DD, Jessee J, Seidman MM. Proximal and distal effects of sequence context on ultraviolet mutational hotspots in a shuttle vector replicated in xeroderma cells. J Mol Biol. 1994; 236:491-502. doi: 10.1006/ jmbi.1994.1160. 